\title{
Hoax, "Image-Building", and Democracy in Aceh
}

\author{
A Manan ${ }^{1}$, R S Putra ${ }^{2}$ \\ Universitas Islam Negeri (UIN) Ar-Raniry Banda Aceh ${ }^{1,2}$ \\ \{abdul.manan@ar-raniry.ac.id ${ }^{1}$, rahmad.j500@gmail.com² ${ }^{2}$,
}

\begin{abstract}
Hoax is universally defined as fake information, deceived news or, twisted or "made up" facts used for both "gag" and serious matters. The purpose of this study is to examine the "hoax" and its implications toward democracy and development in Aceh. This research uses a socio-phenomenological approach by applying three different techniques of data collection: observation, interviews, and documents. This study revealed that hoax is one form of information created by few individuals to purposively influence their political opponents which then may cause a disturbance, panic and massive fear. Hoax information has been well and purposively designed and made up before it was spread, so as if the information is seemingly true. Hence, it has caused restlessness among the Acehneses and eventually resulted in a panic attack in Democratic Party 2019. The rumor and issue have been a binding part of the Acehnese society, disturbing the democracy and disunity in the society. The issue related to religion is viewed as an effective and advantageous factor to promote conflicts.
\end{abstract}

Keywords: Hoax, Democracy, Aceh

\section{Introduction}

Hoax is a phenomenon that is interesting to be studied. In human history, a hoax has become a powerful weapon in affecting human to create a social conflict in society. Discussing hoax phenomenon, there are many literatures that note its consequences and implications. The term "hoax" means fake or untrue news. In the Islamic perspective, people are prohibited to do the action of a hoax. The statement that relates to the prohibition from hoax has been asserted in the holy Qur'an, in Surah Al-Hujarat (49: 6)," O you who have believed, if there comes to you a disobedient one with information, investigate, lest you harm a people out of ignorance and become, over what you have done, regretful."From this verse, it can be concluded that God has given His guidance for all humans to act carefully, not to be reckless and injudicious in absorbing information, especially if it comes from someone who is recognized over his lies and wickedness. The aforementioned verse also reminds Muslims to do the clarification (tabayyun) when they receive some news from unknown persons.

Islam had discussed the prohibition toward Hoax for a long time ago. However, it is hard to deny that the advancement of technology somehow brings not only positive effects but also inevitably negative ones, especially through the channel of social media. One of the phenomena happened recently over the implications and easiness of technology access is the popularity of hoax or fake information. It is called "fake" because it is taken from unclear and untrusted sources, easily spreading in social media and chatting apps without any clarified 
information. Thus, the information is capable to deceive the users as it is expected by a few people. A hoax can be easily found and supportively conducted by people who are familiar with internet access, social networks, and instant messaging [1].

Maulana, in his study [2], mentioned that the emergence of social media such as Facebook and Twitter have mediated their users to receive and disseminate news and information in the form of pictures and videos. In just 30 seconds, hoax can be easily sent to all people across the world. The simplicity of disseminating information using technology becomes an effective factor to spread a hoax, especially through unlimited and anonymous accounts in social media, so they can speculate about something as they want. To be concerned, most Indonesian people can be considered as active users accessing various social media such as WhatsApp, Blackberry Messenger, Facebook, Twitter, Instagram and many of those are used to access information. Consequently, there is a great chance to spread hoax [2].

Maulana [2] added that the existence of a hoax in social media is a worrying phenomenon in society. Hoax potentially brings significant negative impacts, like making public opinion in falseness, bringing into conflicts between Muslims, carrying provocative actions that can destroy the unity of Muslims. By saying righteous and honest, the practicality of hoax can be reduced. Furthermore, besides saying the truth, the Qur'an also instructs Muslims to always do clarification toward the news. In fact, this clarification is also very directed at religious leaders to always guard the coming of the news and clarified the truth. By prioritizing and following the steps of the Qur'an, Muslims must follow and emulate the call of the Qur'an in order to overcome and minimize the circulation of hoax [2].

Hartono [3] in Gumilar et. al [4] cited that: "A study conducted by Fahmi revealed that $92.40 \%$ of hoax spreading in Indonesia was mediated through social media (Facebook, Twitter, Instagram, and Path), respectively $62.80 \%$ hoax coming from chatting apps (WhatsApp, Line, and Telegram) and followed by Web Sites by $34.90 \%$. Meanwhile, according to the format, $62.10 \%$ hoax was delivered in a written form, whereas $37.50 \%$ was in images and dimension forms [4]. Fahmi's research(2017) found that the most popular category of hoax in Indonesia was about political and social issues $(91.80 \%)$ related to the current local political election and government policy. In the second place was issues related to ethnicity, religion, and race among local groups (SARA) by $88.90 \%$ and followed by the issues of health in the third-place [3].

During the Local Political Election in 2018, the "black campaign" and hoax became the two most popular terms used by few people in social media to win their political rivalry by presenting a misleading argument to "conquer" and convince many people. The Election Supervisory Board (Bawaslu) and the Ministry of Communication and Information (Kominfo) on Wednesday, 31 January 2018 signed the agreement to synchronously supervise and monitor the internet contents during the General Election as whole areas in Indonesia [5]. A lot of false news was shown up and uploaded on social media, triggering the disunity between two groups of people. This conflict happened in a relatively long time and there were also many websites and online personal accounts newly created just to spread the news that blame and "bully" other groups.

Similarly, the growth and development of hoax are considerable significant Aceh, a province located at the very edge of Sumatera Island and in the very west part of Indonesia. The local newspaper, Media Serambi Indonesia, reporting from CNN Indonesia (18/01/2018), mentioned that Aceh is an area with the highest level of hoax acceptance in Indonesia. The fact was based on a survey conducted by the Indonesian Institute of Sciences (LIPI) in 2018 [6]. A study by Fitrianingsih and Ulya [7] mentioned that there are motives behind the existence of hoax dissemination. Religion has become the most popular issue that is 
highlighted [7]. The development of hoax in Aceh as an Islamic regulated region needs to seriously alert. As the national event of a general election is nearly coming in 2019, Rudiantara as Minister of Indonesian Ministry of Communication and Information pointed out that the percentage of hoax during General Election might be increasing significantly up to $30 \%$ from all total Hoax obtained by Kominfo [8]. Therefore, some cases and considerations above have encouraged the researchers to conduct a study on the development of hoax in this province. Furthermore, during General Election later in 2019, certain people will likely use hoax as the strategy to win the election.

\section{Method}

This research is descriptive and qualitative. The data derived from library and field researches using a phenomenology approach that produces either written and oral words uttered by people. Observation has been also conducted to obtain a deeper meaning about the hoax and its implications for democracy in Aceh. A descriptive method was used to examine the problems of the research. The process of data analysis was done continuously from the beginning until the end, from the field or outside, the activity of which included encompassing and noting the data, coding, and interpreting various information obtained in every step of the research.

\section{Result and Discussion}

This research was conducted in a six-month period (starting from 12 September 2018 to 30 April 2019), during which hoax distribution in Aceh was very significant. Hoax in Aceh has a close relationship with a discussion on social-religious issues. In terms of practical politics covered in democracy, a hoax in Aceh is used by a certain group as the option to convince another group whose political preference can be influenced [9]. In Aceh, a "religious figure" may be a noble and an honored person, but in politics, his "holiness" can be easily faded through hoax spread by a certain group [10].

Hoax is done by spreading particular information without any means of responsibility. Some of this information has been always kept and preserved based on the decision that depends on the effect which will emerge later. If hoax can bring positive effects for political practice, the hoax will be maintained through all apological arguments, and vice versa, if hoax carries negative effects, then it will be revised by all means. For instance, a political party that has already played hoax under the "issue of religion" will be "at the crossroad" when the opponents played a similar issue. In this circumstance, they will do self-reflection and revision, whether they will keep the issue as a weapon against other political opponents or revise and turn it into another issue. Next, if they think that the "issue of religion" is still effective and beneficial from its distribution, they will keep spreading the hoax. Another example is when a certain political group, which has already campaigned to the public that they will select one of the religious figures (ulama) as the candidate for presidency but canceled it for some reasons, they will compel to replace the candidate of vice president with one of those "religious figures" by convincing arguments.

The research finding also revealed that in order to keep the action above, they will execute gradually or do it all at once. In the former, they will convince the public that their candidate for vice-president is a former Islamic school student (santri). In order to gain the public's trust with this "claim", they will look for accurate arguments through a method of "matching" or "cocoklogi". Soon after the public is convinced, the status of santri will not be embodied as a 
"religious figure" (ulama) through "inauguration" and there will be a millennial religious figure. If this hoax strategy turned out to be ineffective, they will pick another strategy by revising that the religious figure (ulama) is not qualified to become a politician. The practice of politics in Aceh also plays a strategy in which hoax is used as a media for raising the issue of "image-building" (pencitraan). It works, for instance, when few people are recognized as bad, wicked and stubborn, but once they come into a political arena, they will transform themselves into a kind and devout persons. Uniquely, many people believe in this kind of ridiculous manipulation, saying that they have already repented. Thanks to social media, this kind of action is happening widely and wildly in cyberspace.

In another case, after the withdrawal of the candidate number of the Presidential and Vice President of Indonesia, the "winning team" of each pair in Aceh also interpreted the news about the serial number with various narratives deemed to benefit their candidates. For example, for the candidate who gets number 1 for election numbers, they interpreted that the number represents a victory. They often "copy/hijack" the verses from the Qur'an to justify their interpretations. For instance, they interpreted that number 1 is the symbol of monotheism (tauhid). Similarly, the winning team of candidate number 2 interpreted that "two" represents the legacy of the Prophet Muhammad for their followers (ummat): the Qur'an and the Hadits. Therefore, this becomes a strong message for people to choose them.

Furthermore, it is possible that candidate number one will see this as the opportunity to defeat the candidate number two by claiming that number "two" does not represent the "tauhid", rather it means doing "shirk" toward God. On the contrary, the candidate number cited two will counter the opponent by saying "one is enough" meaning that they can not be elected for the second time. This debate often confuses people and goes viral in social media. In today's Android era, this phenomenon has influenced many people of all ages. The Acehnese people now are being easily manipulated and persuaded to attack, humiliate, and blackguard each other. The war has inevitably taken place in social media through false news and information which later become the most popular weapon to win the political battle.

Paying attention to this development, the popularity of social media carries out comments and post-comments in social media, especially in Facebook, all day long.. The politician and political observers are enthusiastic to analyze the national political map, especially toward the contestants of President and Vice President of the Republic of Indonesia. They are seriously posting their arguments that they believe to be true. Interestingly, like other winning teams of President and Vice President, the political observers in social media are also divided into two major political groups, i.e. Jokowi vs. Prabowo. This reality then made the political observers in social media turn themselves to pretendedly become the winning team, even though they will never admit it. The presence of political observers in social media brings the consequence toward hoax-based campaigns in social media because of which the Acehnese people are divided into two major political sides. Thus, this phenomenon influences the Acehnese people to be involved in the practice of Hoax.

According to the data obtained from the questionnaire, there are clusters of hoax dissemination in Aceh, particularly in social media. Several social media are often used as a tool to do a hoax-based campaign, such as WhatsApp, Line, Instagram, Facebook, and Twitter. The percentage of hoax distribution on social media for six months (September-April 2019) can be seen in the following tables:

\section{Whatsapp}


Based on the questionnaire, there was a significant increase in the proportion of hoax distribution through WhatsApp, particularly during the 2019 democracy event. The percentage of hoax distribution through WhatsApp is shown in the table and figure below:

Table 1. Percentage of Hoax Dissemination, September - April 2019 in WhatsApp

\begin{tabular}{clcc}
\hline NO & MONTH & PERCENTAGE & $\begin{array}{c}\text { SOCIAL } \\
\text { MEDIA }\end{array}$ \\
\hline 1 & SEPTEMBER & $74.50 \%$ & \\
2 & OCTOBER & $75.65 \%$ & \\
3 & NOVEMBER & $78.67 \%$ & $80.65 \%$ \\
4 & JANUARY & $84.85 \%$ & \\
5 & MARCH & $90.55 \%$ & \\
6 & APRIL & & \\
\hline
\end{tabular}

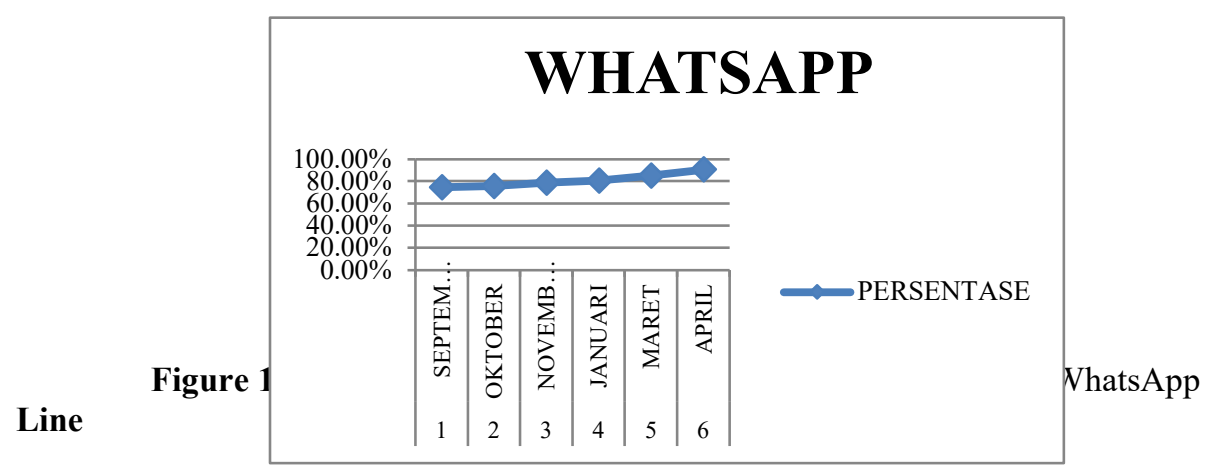

Based on the questionnaire, there was a significant increase in the spread of hoax through this application. The percentage of hoax distribution through Line during September-April is shown seen in the table and figure below:

Table 2. Percentage of Hoax Distribution, September - April 2019 in Line

\begin{tabular}{clcc}
\hline NO & MONTH & PERCENTAGE & $\begin{array}{c}\text { SOCIAL } \\
\text { MEDIA }\end{array}$ \\
\hline 1 & SEPTEMBER & $71.00 \%$ & \\
2 & OCTOBER & $71.12 \%$ & \\
3 & NOVEMBER & $73.80 \%$ & \\
4 & JANUARY & $75.05 \%$ & Z \\
5 & MARCH & $78.08 \%$ & \\
6 & APRIL & $80.15 \%$ & \\
\hline
\end{tabular}

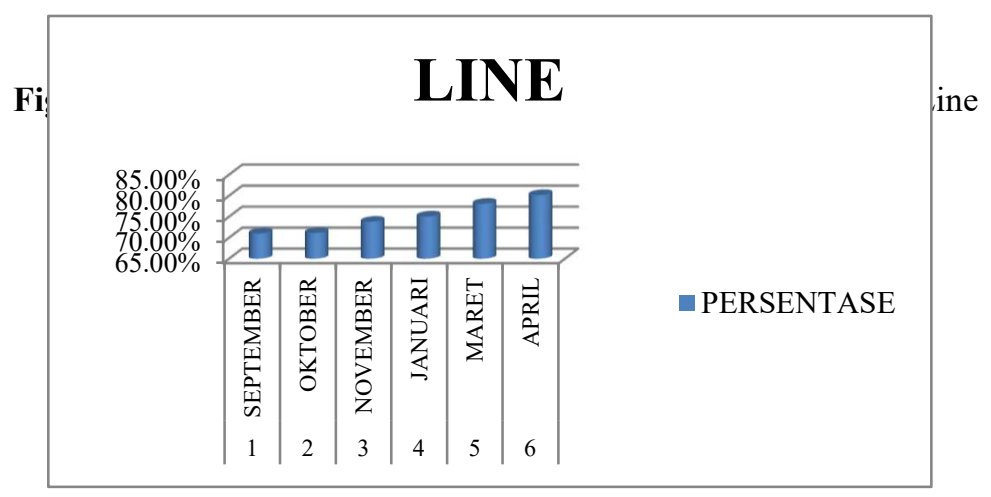




\section{Instagram}

According to the research findings obtained from the questionnaire, hoax dissemination through Instagram got a sharp increase in the last six months from September - April 2019. The percentage of the increase is shown in the table and figure below:

Table 3. Percentage of Hoax Dissemination, September - April 2019 in Instagram

\begin{tabular}{clcc}
\hline NO & MONTH & PERCENTAGE & $\begin{array}{c}\text { SOCIAL } \\
\text { MEDIA }\end{array}$ \\
\hline 1 & SEPTEMBER & $74.58 \%$ & \\
2 & OCTOBER & $75.68 \%$ & \\
3 & NOVEMBER & $78.68 \%$ & 先 \\
4 & JANUARY & $80.50 \%$ & 年 \\
5 & MARCH & $85.80 \%$ & \\
6 & APRIL & $91.46 \%$ & \\
\hline
\end{tabular}

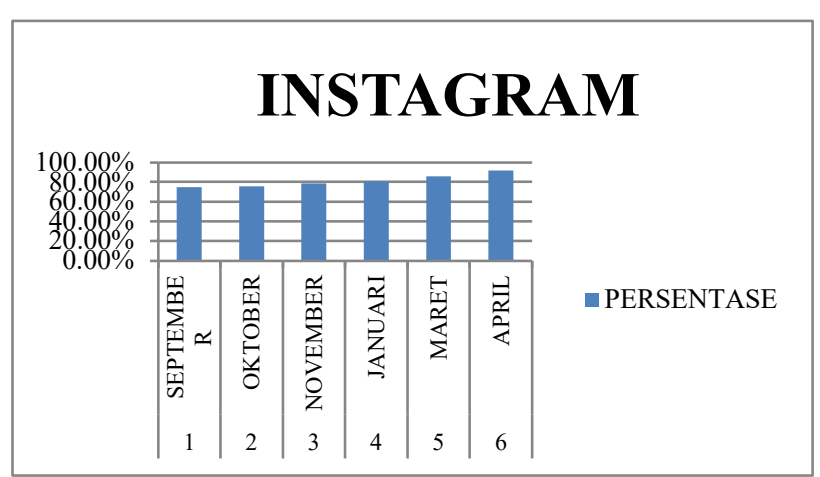

Figure 3. Level of Hoax Distribution, September- April 2019 in Instagram

\section{Facebook}

The results of the questionnaire indicated that hoax dissemination had increased sharply through Facebook in the last six months from September - April 2019. The percentage of its increase is shown in the table and figure below:

Table 4. Percentage of Hoax Distribution, September - April 2019 in Facebook

\begin{tabular}{|c|c|c|c|}
\hline NO & MONTH & PERCENTAGE & $\begin{array}{l}\text { SOCIAL } \\
\text { MEDIA }\end{array}$ \\
\hline 1 & SEPTEMBER & $74.55 \%$ & \multirow{6}{*}{ 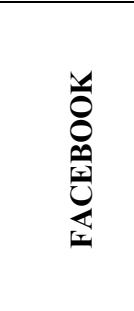 } \\
\hline 2 & OCTOBER & $76.80 \%$ & \\
\hline 3 & NOVEMBER & $79.73 \%$ & \\
\hline 4 & JANUARY & $80.98 \%$ & \\
\hline 5 & MARCH & $88.78 \%$ & \\
\hline 6 & APRIL & $95.32 \%$ & \\
\hline
\end{tabular}




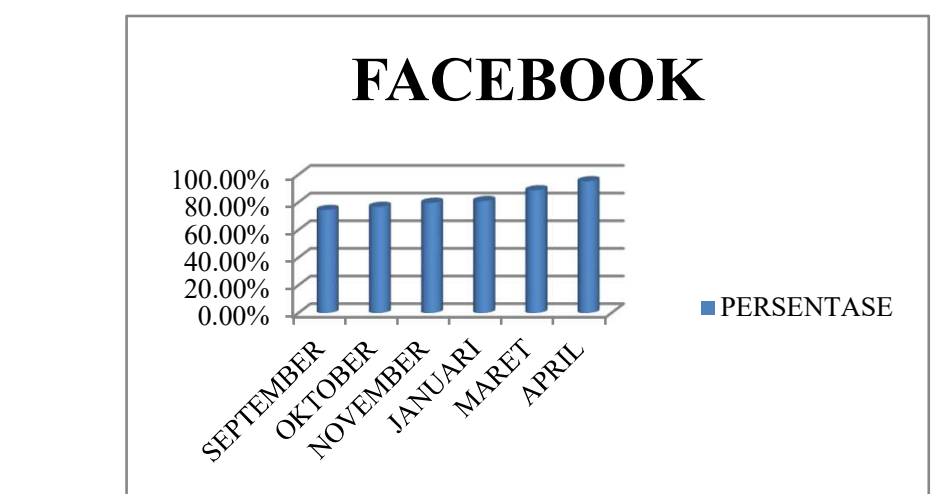

Figure 4. Level of Hoax Distribution, September- April 2019 in Facebook

\section{Twitter}

The level of hoax dissemination is also significantly high on Twitter. There were some fake Twitter accounts that retweeted more than the real users. The percentage of its increase is shown from the table and figure below:

Table 5. Percentage of Hoax Dissemination, September - April 2019 in Twitter

\begin{tabular}{clcc}
\hline NO & MONTH & PERCENTAGE & $\begin{array}{c}\text { SOCIAL } \\
\text { MEDIA }\end{array}$ \\
\hline 1 & SEPTEMBER & $70.18 \%$ & \\
2 & OCTOBER & $71.01 \%$ & \\
3 & NOVEMBER & $75.42 \%$ & \\
4 & JANUARY & $80.01 \%$ & \\
5 & MARCH & $83.09 \%$ & \\
6 & APRIL & $90.03 \%$ & \\
\hline
\end{tabular}

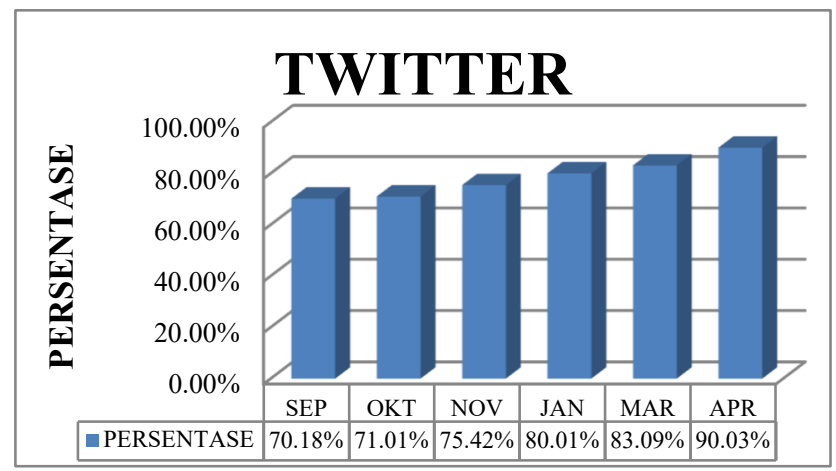

Figure 5. Level of Hoax Distribution, September- April 2019 in Twitter 
The recapitulation of the research findings on hoax distribution in the last six months, from September to April 2019, in those five different social media revealed that Facebook became the most popular social media network used to spread a hoax and fake news, followed by WhatsApp in the second place, Instagram, Line and lastly Twitter. The recap can be seen in the following table:

Table 6.Total Percentage of Hoax Distribution, September-April 2019

\begin{tabular}{clccccc}
\hline NO & MONTH & WHATSAPP & LINE & INSTAGRAM & FACEBOOK & TWITTER \\
\hline 1 & SEPTEMBER & $74.50 \%$ & $71.00 \%$ & $74.58 \%$ & $74.55 \%$ & $70.18 \%$ \\
2 & OCTOBER & $75.65 \%$ & $71.12 \%$ & $75.68 \%$ & $76.80 \%$ & $71.01 \%$ \\
3 & NOVEMBER & $78.67 \%$ & $73.80 \%$ & $78.68 \%$ & $79.73 \%$ & $75.42 \%$ \\
4 & JANUARY & $80.65 \%$ & $75.05 \%$ & $80.50 \%$ & $80.98 \%$ & $80.01 \%$ \\
5 & MARCH & $84.85 \%$ & $78.08 \%$ & $85.80 \%$ & $88.78 \%$ & $83.09 \%$ \\
6 & APRIL & $90.55 \%$ & $80.15 \%$ & $91.46 \%$ & $95.32 \%$ & $90.03 \%$ \\
\hline
\end{tabular}

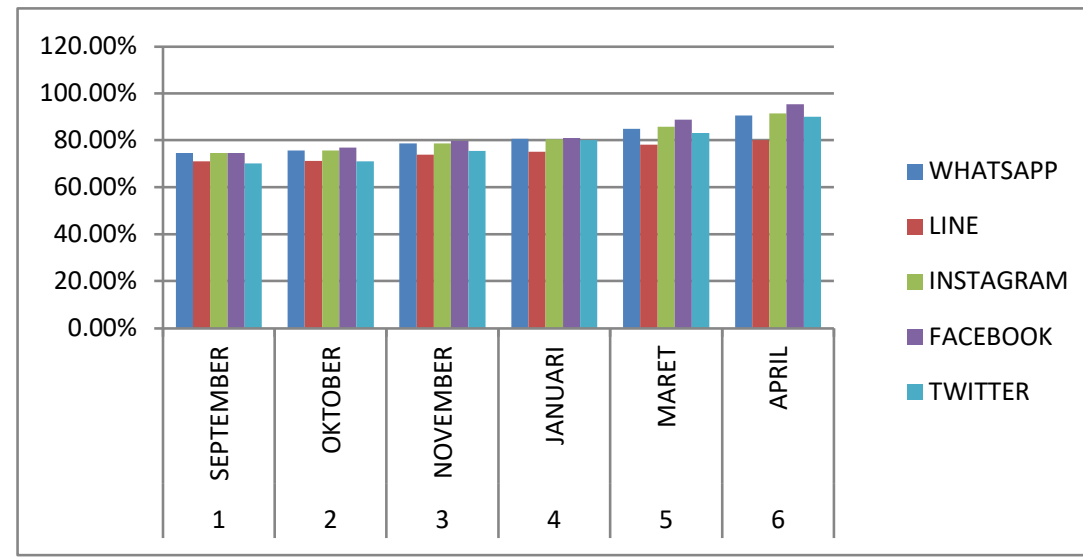

Figure 6.Total Percentage of Hoax Distribution, September-April 2019

From the total percentage (table and figure) above, it can be concluded that most people tended to use Facebook as a media to share information, followed by WhatsApp, Instagram, Line and finally Twitter. The use of handphones and smartphones had fastened the distribution of hoax information and also become the media to influence people to get involved in the political debates. In other words, there were various strategies in terms of distributing hoax done by a particular group to gain their existence, one of them is through social media. They expected that social media had a chaotic contribution to produce some "popular" figures and actors temporarily; for instance, figures who were unrecognizable suddenly became famous just by updating their status and posting their comments on Facebook, Twitter, and Instagram. They later become charismatic figures with numbers of fanatic followers.

The researcher also found out that the impact of hoax to gain sympathy from the public is that plenty of supporters spent their energy and time interacting with social media for months until Election Day. This indicated that hoax dissemination in the political election in 2019 had become a powerful weapon to claim a political victory in the election. Social media has become a potent field for them to grab sympathy. All the previous awards, compliments, achievements are now splashed into the public to get their votes. Hence, it can be presumed 
that the election is no safer and secret as everyone now can say anything on social media as a form of "image-building".

In addition, the hoax distributor deployed several strategies to manipulate people in Aceh by addressing the issue in threads and comments on social media. Even, some people suddenly become experts in all areas, such as economy, agriculture, marine, petroleum, trades, education politic, and even religion. These "temporary" or "pretending" experts are willing to spend their time to create some issues and to support their candidates through social media. They are often fond of disputes to keep and defend their own arguments, for instance, by bullying the candidate A by titling his opponents as "Cebong" and the candidate B as "Kampret".

The phenomenon resulted from this research indicated that some of them believed that they are the most Indonesian, the most millennial, the most intelligent, the most religious, or even the most handsome. They were dissolved deeply into their own imagination and hallucination as if they could change their destiny soon. They feel more motivated than the real and official winning team. They even forgot about their lives. The hoax had poisoned democracy in Aceh.

This research suggested that hoax had confused many people in Aceh, and even they were totally manipulated. This implicated that hoax had ruined democracy in Aceh because people were disunited, especially related to the political issue in 2019 Presidential and General Election. Even, a hoax was also used as a form of provocation and negative agitation to incite hatred, anger, incitement to people (to conduct riots, etc.), and was usually also carried out by religious leaders and activists through fiery speeches to influence the masses. Then, a hoax in Aceh was also negative propaganda as a deliberate and systematic effort to shape perception, manipulation of nature, thoughts or cognition and directly influence behavior in order to respond according to the wishes of the propaganda actors with the political aim to support their groups in the Presidential Election and General Election 2019.

\section{Conclusion}

Hoax is considered "made-up" information created by a few groups of people to attack their political opponents. It has caused panic and fear in the mass and has worsened the condition during 2019 Presidential and General Election. Democracy in Aceh would be in danger as the unity of the Acehneses was disturbed due to hoax. Religiusisssues had become the most effective aspect that could trigger chaos and debates. Hoax now can be easily disseminated within various forms of social media, such as WhatsApp, Line, Instagram, Facebook, and Twitter. The data found that Facebook had become the most popular form of media social used by people to spread a hoax, followed by WhatsApp, Instagram, Line and lastly Twitter.

\section{References}

[1] R. Istriyani, "Etika Komunikasi Islam dalam Membendung Informasi Hoax di Ranah 
Publik Maya,” J. Ilmu Dakwah, vol. 36, no. 2, 2016.

[2] L. Maulana, "Kitab Suci dan Hoak: Pandangan Al-Qur'an dalam Menyikapi Berita Bohong," Wawasan (Jurnal Ilm. Agama dan Sos. Budaya), vol. 2, no. 2, p. 219, 2017.

[3] D. Hartono, "Era Post Trush: Melawan Hoak dengan Fact Cheking," in National Seminar Government Study Program UNPAD, 2018.

[4] G. Gumilar, "HOAX, REPRODUKSI DAN PERSEBARAN: SUATU PENELUSURAN LITERATUR," UNPAD, 2017.

[5] B. Mansyah, Fenomena Berita Hoax Media Sosial (Facebook) dalam Menghadapi Pemilihan Umum Gubernur DKI Jakarta Tahun 2017. Bandung: Fakultas Ilmu Sosial dan Ilmu Politik Universitas Pasundan, 2017.

[6] K. Miswar, "Aceh 'Serambi Hoaks'?," serambinews.com, 2019. .

[7] S. B. U. Fitrianingsih, "Realitas Hoax dalam Pandangan Al-Qur'an,” Literasiologi, vol. 1, pp. 88-89, 2018.

[8] Rudiantara, "Hoax dan Implikasinya Terhadap Demokrasi dan Pembangunan Berkeadilan," in Presentation material at the National Seminar held by the Presidential Staff Office (KSP), 2019.

[9] "The result from observation in the city of Banda Aceh." Banda Aceh, 2019.

[10] "Researcher's observation at Islamic Boarding Schools in the city of Banda Aceh and Aceh Besar in December." Banda Aceh, 2019. 